\title{
Erratum to: Climate Change Communication in Nepal
}

Anup K. C.

\section{Erratum to:}

Chapter "Climate Change Communication in Nepal" in: W. Leal Filho et al. (eds.), Handbook of Climate Change Communication: Vol. 2, Climate Change Management, https://doi.org/10.1007/978-3-319-70066-3_2

The original version of the book was inadvertently published without changing the author name from "K. C. Anup" to "Anup K. C." in the chapter "Climate Change Communication in Nepal", which has been now changed.

The updated online version of this chapter can be found at https://doi.org/10.1007/978-3-319-70066-3_2 